\title{
ANALISA GANGGUAN STATOR MOTOR INDUKSI FASA 3 DENGAN METODE CURRENT SIGNATURE ANALISIS DAN MONITORING TEMPERATUR
}

\author{
Dede Zaenal ${ }^{1}$ \\ ${ }^{1}$ Prodi Teknik Elektro UNPAM \\ Jln. Puspiptek Raya No 46 Buaran, Setu - Tangerang Selatan 15310 \\ Dedezaenalbt@yahoo.com
}

\begin{abstract}
ABSTRAK
Gangguan isolasi pada lilitan stator akan mengakibatkan tambahan hubung singkat pada lilitan, tambahan kenaikan temperatur, dan semakin memperpendek umur isolasi lilitan. Analisa kerusakan pada stator motor induksi sangat dibutuhkan untuk mencegah kerusakan yang lebih besar yang dialami oleh motor induksi fasa tiga. Penelitian ini akan dibahas mengenai analisa gangguan stator motor induksi fasa tiga dengan mendeteksi perubahan arus, memonitor perubahan temperatur dan menganalisa spektrum gelombang Fast Fourier Transform (FFT) dari signal arus yang diakibatkan dari gangguan hubung singkat lilitan stator. Gangguan stator yang dianalisa adalah gangguan hubung singkat satu fasa (short turn fault) dengan variasi gangguan $20 \%, 25 \%$ dan $30 \%$, dengan menggunakan motor induksi fasa 3 jenis sangkar tupai serta metode deteksi motor current signature analysis (MCSA) dengan menganalisa spektrum gelombang FFT (fast fourier Transform) dari signal arus motor induksi menggunakan software labView dan hardware $\mathrm{NI}$ USB 6009, serta menganalisa perubahan temperatur motor induksi dengan memperhatikan perbedaan nilai temperatur antara lilitan normal dan lilitan yang mengalami gangguan saat kondisi motor tanpa beban dan dengan beban $25 \%$ dan beban $50 \%$. Sensor IC LM35 sebagai sensor temperatur yang diletakan pada lilitan stator normal dan lilitan stator yang mengalami gangguan stator pada motor induksi fasa 3.Gangguan stator motor induksi fasa 3 mengakibatkan meningkatnya nilai arus saat terjadi gangguan pada salah satu fasa nya, dan peningkatan nilai arus tersebut berbanding lurus dengan persentase jumlah gangguan yang terjadi. Kenaikan nilai temperatur pada lilitan yang mengalami gangguan lebih cepat meningkat saat terjadi gangguan stator dan terjadi perbedaan nilai temperature antara lilitan normal dan lilitan yng mengalami gangguan. Gaguan stator juga mempengaruhi nilai slip motor induksi fasa 3 dimana nilai slip Semakin meningkat saat terjadi gangguan begitupula nilai torsi motor semakin meningkat saat stator mengalami gangguan kenaikan nilai slip dan torsi terlihat signifikan saat motor diberikan beban. Perbedaan spektrum gelombang FFT arus sangat terlihat antara kondisi motor normal dan mengalami gangguan, noise frekuensi pada signal yang dihasilkan pada sepktrum gelombang FFt semakin bertambah dan nilai noise pada masing - masing pengujian memiliki peningkatan nilai seiring dengan bertambahnya persentase kerusakan stator motor induksi fasa 3 .
\end{abstract}

Kata kunci: Motor induksi fasa 3, Motor Current Signature Analysis (MCSA), gangguan stator sefasa, FFT (fast fourier transform), LabView

\section{ABSTRACT}

3 Phase Induction Motor Stator Interference Analysis with Motor Current Signature Analysis and Temperature Monitoring. The isolation noise on the stator winding will result in additional short circuit in the winding, additional temperature rise, and further shortening the life of the winding insulation. Damage analysis on the induction motor stator is needed to prevent the greater damage experienced by the three phase induction motors. This research will discuss about the analysis of stator induction of three phase induction motors by detecting current changes, monitoring temperature changes and analyzing the Fast Fourier Transform (FFT) wave spectrum of the current signal resulting from the short circuit breakdown of stator windings. The stator disturbance analyzed is a short-circuit fault with $20 \%, 25 \%$ and $30 \%$ disturbance variation, using 3 phase induction motors of squirrel cages as well as current signature 
analysis motor (MCSA) detection method by analyzing the wave spectrum FFT (fast fourier transform) of the induction motor current signal using labView software and hardware NI USB 6009, and analyzes the induction motor temperature change by observing the difference of temperature value between normal winding and winding which is disrupted at motor condition without load and with load $25 \%$ and load $50 \%$. LM35 IC sensor as a temperature sensor placed on normal stator winding and stator windings that suffered stator disturbance in phase 3 induction motors. The stator induction of the 3 phase induction motors results in an increase in the current value during an interruption of one of its phases, and the increase of the current value is directly proportional to the percentage of the number of disturbances. The increase of temperature value on the winding that experienced faster interference increased during stator disturbance and there is a difference of temperature value between normal winding and winding yng experience disturbance. Stator's doubts also affect the slip value of induction motor of phase 3 where the slip value is Increased during interruption as well as the motor torque value increases as the stator experiences an increase in slip value and torque is noticeable when the motor is loaded. The difference of current wave FFT spectrum is very visible between normal motor condition and disturbance, frequency noise in signal generated at wave FFT spectrum increase and noise value in each test has increased value along with increasing percentage of stator damage of induction motor of phase 3.

Keywords :3 phase induction motor, Current Signature Analysis (MCSA) motor, stator interruption in phase, FFT (fast Fourier transform), LabView

\section{PENDAHULUAN}

$P^{b}$ urvei gangguan telah melaporkan bahwa dari gangguan motor disebabkan oleh gangguan terkait bantalan (Bearing) sebesar $40 \%$, oleh gangguan lilitan stator sebesar $38 \%$, oleh gangguan terkait rotor sebesar $10 \%$ dan oleh gangguan campuran yang mempengaruhi bagian lain dari motor induksi sebesar $12 \%$. Hal ini jelas bahwa lilitan stator adalah salah satu sumber yang sering mengalami kerusakan di motor induksi. Gangguan isolasi pada lilitan stator mengakibatkan hubung singkat pada belitan, kenaikan temperature motor, dan mempersingkat usia isolasi lilitan.

Hubung singkat dari sejumlah kecil putaran tidak memiliki tanda - tanda fisik yang besar, tetapi dapat mengakibatkan terjadinya gangguan isolasi dalam waktu yang relative singkat, dalam hal ini dibutuhkan analisis untuk mendeteksi gangguan kerusakan khususnya pada gangguan lilitan stator sehingga dapat mengantisipasi kemungkinan terjadi tingkat kerusakan yang lebih besar pada lilitan stator.

Untuk mendeteksi gangguan yang diakibatkan dari lilitan stator dibutuhkan seperangkat sistem yang mampu memantau kondisi motor, salah satu metode analisis salah satunya adalah Data Acquisition System (DAS). Fungsi utama dari DAS adalah untuk mengolah sinyal dari sensor yang biasanya berupa sinyal analog yang dirubah menjadi sinyal digital, kemudian sinyal digital tersebut diberikan kepada sistem berikutnya untuk kemudian diolah dan dimanfaatkan.

Dalam pendeteksian kerusakan motor dibutuhkan metode khusus yang digunakan dalam penelitian dan MCSA (Motor Current Signature Analysis) adalah metode analisis yang sangat sering dipergunakan untuk mendeteksi gangguan kerusakan motor induksi dan salah satunya adalah kerusakan stator motor.

Sesuai dengan analisa pada pernyataan diatas penelitian memiliki tujuan sebagai berikut:

1. Membuat Program data akuisisi dengan menggunakan software labview untuk monitoring dampak dari gangguan short turnstator motor induksi fasa tiga.

2. Mengetahui perubahan nilai arus dan nilai temperatur yang dihasilkan motor induksi fasa tiga ketika dalam kondisi stator mengalami gangguan.

3. Mengetahui perubahan bentuk spektrum gelombang FFT dari signal 
arus saat kondisi normal dan mengalami gangguan.

4. Mengetahui dampak gangguan short turnstator motor induksi fasa tiga terhadap effisiensi, torsi, slip.

\section{TEORI}

\section{Motor Induksi Tiga Phasa}

Motor induksi tiga Phasa adalah salah satu jenis motor listrik arus bolak balik (AC) yang dimana nilai putaran rotornya berbeda nilai putaran medan stator, dan dapat juga dikatakan bahwa nilai putaran rotor dengan nilai putaran pada medan stator memiliki selisih putaran dan hal ini yang disebut dengan slip.

Motor induksi adalah salah satu motor dengan konstruksi yang baik, harganya relative lebih murah serta mudah untuk melakukan pengaturan pada kecepatan, stabil saat dibebani dan memiliki efisiensi yang tinggi. Motor induksi saat ini paling banyak digunakan dalam dunia industri baik skala besar maupun kecil, dan banyak pula digunakan dalam kebutuhan rumah tangga. Motor induksi hanya memiliki satu suplai tenaga listrik yang mengeksitasi lilitan stator. lilitan stator yang di eksitasi oleh tenaga listrik menginduksi lilitan rotor dengan menggunakan perubahan medan magnet yang disebabkan dari arus lilitan stator hal ini dilakukan karena belitan rotor tidak terhubung langsung kepada sumber tenaga listrik.

\section{Prinsip Kerja Motor Induksi Tiga Phasa}

Prinsip kerja motor induksi tiga Phasa didapat berdasarkan pada hukum Faraday dimana tegangan induksi akan ditimbulkan oleh perubahan induksi magnet pada suatu lilitan dan hukum Lorentz dimana perubahan magnet akan menimbulkan gaya, hal ini dijelaskan sebagai berikut:[2]

1. Jika sumber tegangan tiga phasa dihubungkan pada kumparan stator, maka akan timbul medan putar stator dengan kecepatan:

$$
\mathrm{n}_{\mathrm{s}}=\frac{120 . \mathrm{f}}{\mathrm{P}}
$$

dengan:

$\mathrm{n}_{\mathrm{s}} \quad=$ Kecepatan medan putar stator

(rpm)

$\mathrm{f} \quad=$ Frekuensi jaringan $(\mathrm{Hz})$

$\mathrm{P}=$ Jumlah kutub

2. Medan putar stator akan memotong batang konduktor pada rotor, sehingga akan timbul gaya gerak listrik (ggl) induksi pada kumparan stator.

3. Rangkaian rotor merupakan rangkaian tertutup, maka akan timbul arus (I) pada kumparan motor hal ini dikarenakan adanya ggl induksi yang yang dihasilkan dari kumparan stator.

4. Adanya arus $(I)$ di dalam medan magnet akan menimbulkan gaya mekanik $(F)$ pada rotor. Jika torsi mula $(T e)$ yang dihasilkan oleh gaya rotor cukup besar untuk memikul torsi beban ( $T L)$, maka rotor akan berputar searah dengan medan putar statom ${ }_{s}$ dengan kecepatan putar rotor $n_{r}$

5. Perbedaan antara $n_{s}$ dan $n_{r}$ disebut dengan slip $(S)$, dinyatakan dengan:

$$
\mathrm{S}=\left(\frac{n_{s}-n_{r}}{n_{s}}\right) \times 100 \%
$$

6. Apabila $n_{s}=n_{r}$ maka tegangan tidak akan terinduksi dan arus tidak mengalir pada kumparan jangkar rotor, sehingga tidak akan timbul torsi (Te). Torsi akan timbul apabila $n_{r}$ lebih kecil dari $n_{s}$.

\section{Effisiensi Motor Induksi}

Efisiensi motor induksi adalah salah satu parameter yang dipergunakan untuk mengetahui keefektifan motor induksi yang berfungsi mengubah energi listrik menjadi energi mekanis serta sebagai perbandingan antara daya masukan dan daya keluaran atau dalam bentuk energi listrik berupa perbandingan watt keluaran dan watt masukan. Berdasarkan NEMA definisi efisiensi energi adalah bahwa efisiensi merupakan perbandingan atau rasio dari 
daya keluaran yang berguna terhadap daya input total, biasanya hal ini dinyatakan dalam persen dan juga sering dinyatakan sebagai perbandingan antara keluaran dengan masukan dan ditambahkan nilai rugi-rugi, jika dirumuskan dalam persamaan maka definisi effisiensi adalah sebagai berikut: 2.4. [1]

Eff $=\frac{P_{\text {out }}}{P_{\text {in }}}=\frac{P_{\text {out }}-P_{\text {loss }}}{P_{\text {in }}}=\frac{P_{\text {out }}}{P_{\text {in }}+P_{\text {loss }}} \times 100 \%$

\section{Slip Motor Induksi}

Tegangan induksi pada rotor motor tergantung pada kecepatan rotor terhadap medan magnet statomya. Pada motor induksi kecepatan rotor pasti tidak akan pernah sama dengan kecepatan medan magnet statomya. Terjadinya perbedaan antara dua kecepatan tersebut dikarenakan terdapat adanya slip/geseran yang meningkat, seiring dengan menigkatanya beban. Slip ini hanya terjadi pada motor induksi dan besarnya slip dapat dirumuskan sebagai berikut: :[4]

Slip $(s)=\frac{n_{s}-n_{r}}{n_{s}} \times 100 \%$

\section{Dengan:}

$\mathrm{S} \quad=$ Slip

$\mathrm{n}_{\mathrm{s}} \quad=$ Kecepatan medan putar stator (rpm)

$\mathrm{n}_{\mathrm{r}} \quad=$ Kecepatan putar rotor $(\mathrm{rpm})$

\section{Temperatur Motor Induksi}

National Electrical Manufacturing Association (NEMA) menjelaskan temperatur rise didefiniskan sebagai kenaikan temperatur motor melebihi temperatur ambient. Temperatur ambient adalah temperatur udara disekitar motor atau dapat disebut sebagai temperatur ruang pada motor.

Jumlah dari temperatur rise dan temperatur ambient adalah jumlah dari keseluruhan panas pada motor.

Isolasi temperatur pada motor induksi dibagi menjadi beberapa kelas dan dapat dijelaskan sesuai dengan tabel klasifikasi dibawah ini (temperatur ambient tidak lebih dari $40^{\circ} \mathrm{C}$ ).

Tabel 1.Tabel klasifikasi kenaikan temperatur motor induksi

\begin{tabular}{|c|l|c|c|c|c|}
\hline \multirow{2}{*}{ No } & \multirow{2}{*}{ Motor Rating } & \multicolumn{4}{|c|}{$\begin{array}{l}\text { Insulation Class and Temperatur } \\
\text { Rise } \mathrm{C}\end{array}$} \\
\cline { 3 - 6 } & & $\mathrm{A}$ & $\mathrm{B}$ & $\mathrm{F}$ & $\mathrm{H}$ \\
\hline 1 & All horsepower (or $\mathrm{kW}$ ) ratings & 60 & 80 & 105 & 125 \\
\hline 2 & $1500 \mathrm{hp}(1120 \mathrm{~kW})$ and less & 70 & 90 & 115 & 140 \\
\hline 3 & $\begin{array}{l}\text { Over } 1500 \mathrm{hp}(1120 \mathrm{~kW}) \text { and } 7000 \\
\text { volt or less }\end{array}$ & 65 & 85 & 110 & 135 \\
\hline 4 & $\begin{array}{l}\text { Over } 1500 \mathrm{hp}(1120 \mathrm{~kW}) \text { and over } \\
\text { 7000 volt }\end{array}$ & 60 & 80 & 105 & 125 \\
\hline
\end{tabular}

\section{Gangguan Stator Motor Induksi}

Gangguan stator terbagi menjadi dua jenis, yaitu:

1. gangguan di belitan stator

2. gangguan di inti stator.

Penyebab gangguan pada belitan stator adalah disebabkan dari temperatur yang tinggi pada inti stator dan belitan stator, terkontaminasi minyak, lembab, kerusakan di ujung belitan, hubung singkat, akibat pembebanan, pengasutan belitan, electric discharge, dan kebocoran pada system pendinginan. ${ }^{[6]}$ Gangguan stator yang paling umum terkait dengan belitan stator motor induksi adalah: fase ground, fasa -fase dan hubung singkat kumparan dari fasa yang sama atau berbeda. Menurut survei, 35-40\% kegagalan motor induksi disebabkanolehgangguan lilitan stator. Selain itu, umumnya diyakini bahwa sebagian besar gangguan stator yang terjadi dalam satu fase yang sama. Jenis kesalahan ini disebut sebagai "stator turn fault". Gambar 1 di bawah ini menunjukan skema dari gangguan hubung singkat motor induksi tiga fase.[7] 


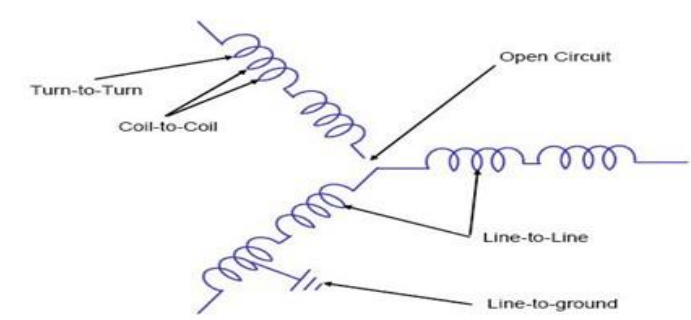

Gambar 1. Skema Hubung Singkat Stator

Terlepas dari penyebabnya, kegagalan terkait statomotor induksi dapat dibagi menjadi lima kelompok:

a. Hubung singkat turn - turn

b. Hubung sigkat coil - coil

c. Hubung singkat Fase - fase

d. Hubung singkat Fase - Ground

e. Open circuit lilitan stator

$\mathrm{Di}$ antara lima mode gangguan stator diatas, gangguan hubung singkat turn turn(stator turn fault) telah dianggap menjadi gangguan yang paling sering terjadi, karena jenis gangguan stator lainnya biasanya merupakan gangguan yang diakibatkan dari gangguan stator turn. [7]

\section{METODOLOGI}

Metode penelitian dalam penelitian ini adalah study literature dan ekperimen. Study literature adalah dengan mengumpulkan data tentang gangguan stator motor induksi fasa 3 dan teori tentang temperatur motor induksi dari berbagai referensi dan ekseperimen yang dilakukan melakukan pengujian motor induksi dengan menggunakan data akuisisi NI USB 6009 dan didukung oleh software labview sebagai penampil data arus, tegangan dan temperatur serta spektum gelombang Fast Fourier Transform) FFT dari signal arus motor.

\section{Rancangan Penelitian}

Dalam penelitian terhadap analisa gangguan stator motor induksi fasa 3 , ada beberapa tahapan yang harus ditempuh berdasarkan flow chart yang telah dibuat. Dari flow chart tersebut dapat dijelaskan metode pengambilan data yang akan dilakukan oleh peneliti. Adapun flow chart penelitian ditunjukan pada gambar 2

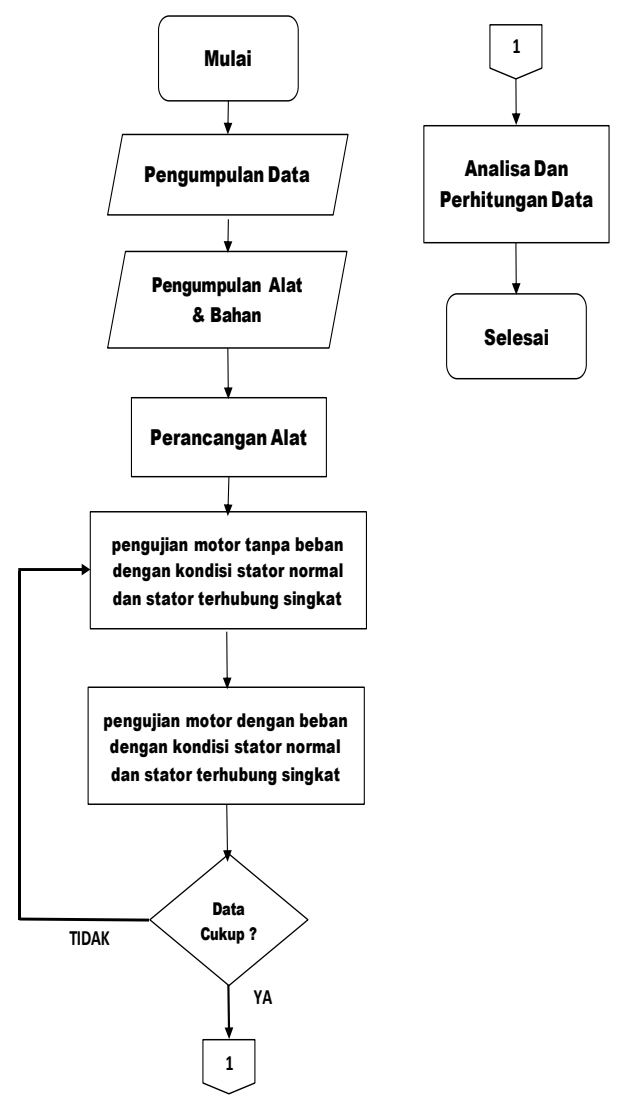

Gambar 2. Flow Chart Penelitian

\section{HASIL DAN PEMBAHASAN}

\section{Pengukuran FFT Arus}

Hasil pengukuran spektrum gelombang FFT pada pegujian gangguan stator motor induksi fasa 3 tanpa beban.

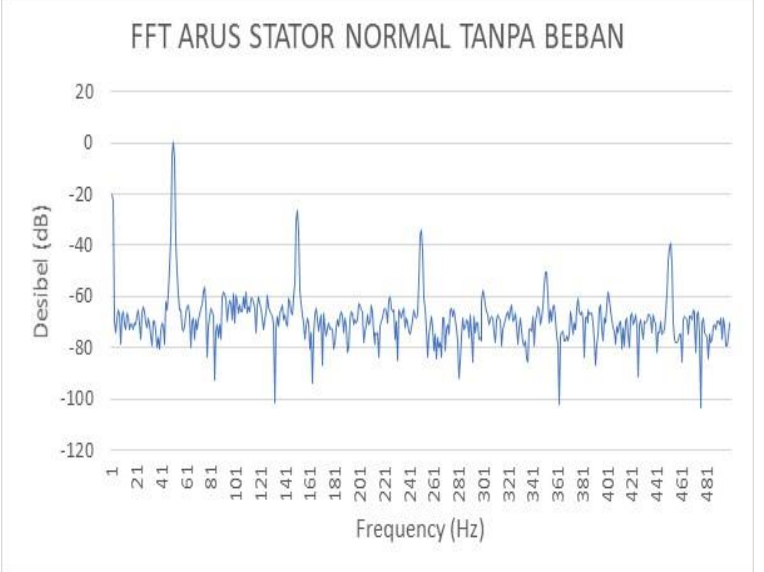

Gambar 3. FFT arus stator normal 


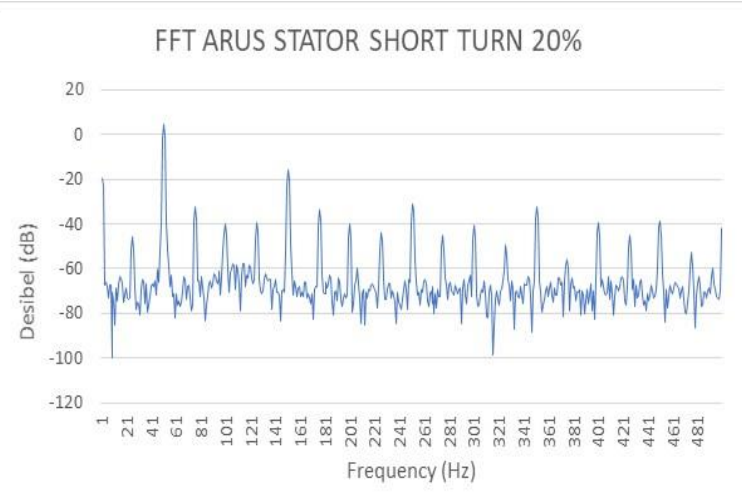

Gambar 4. FFT arus short turn $20 \%$

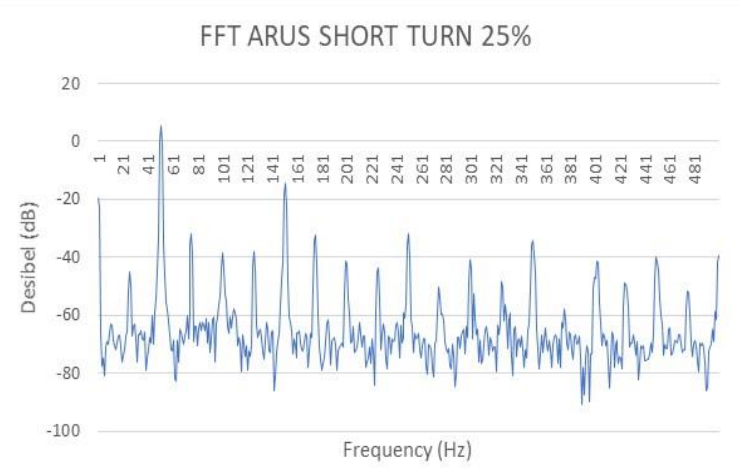

Gambar 5.FFT arus short turn 25\%

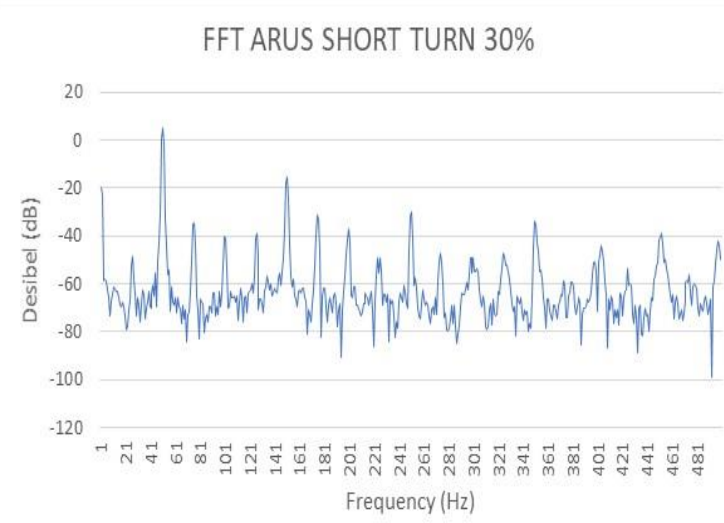

Gambar 6. FFT Arus short turn 30\%

\section{Tabel Pengukuran FFT Arus}

Hasil pengukuran spektrum gelombang FFT arus yang telah dilakukan maka untuk memudahkan dalam perbandingan noise frequency yang dihasilkan dibuatkan tabel rekapitulasi noise frequency pada gelombang FFT arus motor induksi tanpa beban, berikut ini table 2 hasil rekapitulasi noise frequency yang dihasilkan dari pengukuran gelombang FFT arus gangguan motor induksi motor induksi tanpa beban.

Tabel 2. Rekapitulasi FFT arus

\begin{tabular}{|c|c|c|c|c|}
\hline \multirow{2}{*}{$\begin{array}{l}\text { Frequensi } \\
\quad(\mathrm{Hz})\end{array}$} & \multicolumn{4}{|c|}{ Amplitudo (dB) } \\
\hline & Normal & $\begin{array}{l}\text { Short } \\
\text { turn } \\
20 \%\end{array}$ & $\begin{array}{c}\text { Short } \\
\text { turn } \\
25 \%\end{array}$ & $\begin{array}{l}\text { Short } \\
\text { turn } \\
30 \% \\
\end{array}$ \\
\hline 26 & & $-45,633$ & 44,952 & $\begin{array}{c}- \\
48,375 \\
\end{array}$ \\
\hline 51 & 0,392 & 4,638 & 5,453 & 5,26 \\
\hline 76 & & $-32,530$ & $31, \overline{6} 15$ & 34,627 \\
\hline 100 & & & & 40,062 \\
\hline 101 & & $-40,311$ & $\begin{array}{c}- \\
38,529 \\
\end{array}$ & \\
\hline 126 & & $-39,547$ & $\begin{array}{c}- \\
38,167\end{array}$ & $\begin{array}{c}- \\
38,745\end{array}$ \\
\hline 151 & 26,606 & $-15,611$ & 14,372 & 15,051 \\
\hline 175 & & & & 31,005 \\
\hline 176 & & $-33,774$ & 32,255 & \\
\hline 200 & & & 41,329 & $\begin{array}{c}- \\
37,300\end{array}$ \\
\hline 201 & & $-40,203$ & & \\
\hline 226 & & $-43,679$ & $\begin{array}{c}- \\
43,795 \\
\end{array}$ & $\begin{array}{c}- \\
49,257 \\
\end{array}$ \\
\hline 251 & 33,788 & $-30,889$ & 31,977 & 30,165 \\
\hline 274 & & & & $\begin{array}{c}- \\
47,156 \\
\end{array}$ \\
\hline 275 & & & 50,314 & \\
\hline 276 & & $-44,861$ & & \\
\hline 300 & & & 40,971 & \\
\hline 301 & & $-40,408$ & & 49,386 \\
\hline 325 & & & 48,552 & $4 \overline{-} 177$ \\
\hline 326 & & $-49,717$ & & \\
\hline 350 & & & & 33,658 \\
\hline 351 & 50,596 & $-32,164$ & 33,999 & \\
\hline 401 & & $-39,130$ & & \\
\hline 402 & & & $\begin{array}{c}- \\
41,229\end{array}$ & \\
\hline 404 & & & & 44,172 \\
\hline 425 & & & $49, \overline{0} 2$ & $\stackrel{-}{53,446}$ \\
\hline
\end{tabular}




\begin{tabular}{|c|c|c|c|c|}
\hline 426 & & $\begin{array}{c}- \\
445,019\end{array}$ & \\
\hline 450 & & & $\begin{array}{c}- \\
39,871\end{array}$ & \\
\hline 451 & & $-38,484$ & & \\
\hline 452 & $-\overline{-}, 820$ & & & - \\
\hline 475 & & & - & - \\
\hline 476 & & $-52,544$ & & \\
\hline
\end{tabular}

\section{Pengukuran temperatur lilitan motor}

Berikut ini adalah hasil pengukuran temperature lilitan pada pegujian gangguan stator motor induksi fasa 3 tanpa beban.

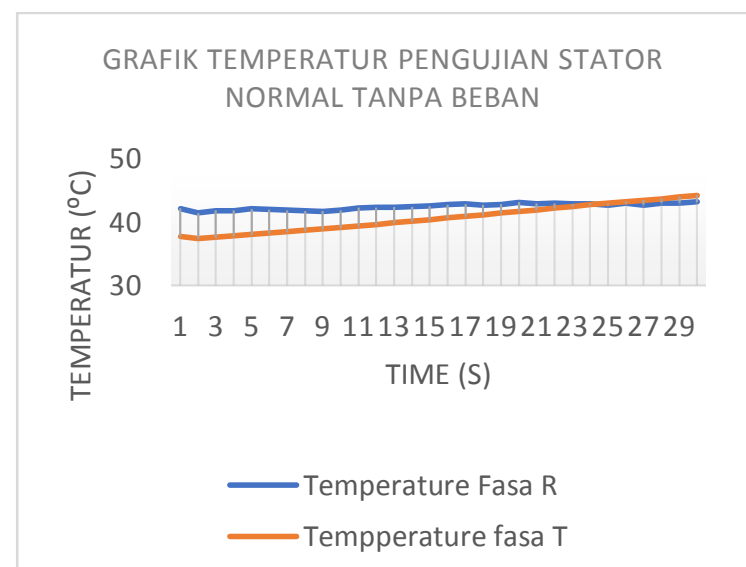

Gambar 7.Temperature stator normal

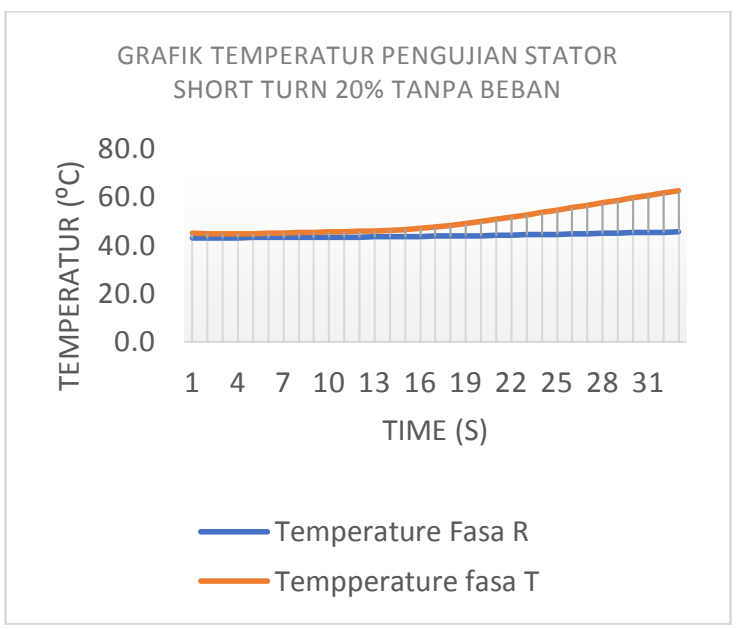

Gambar 8. Temperatur short turn 20\%

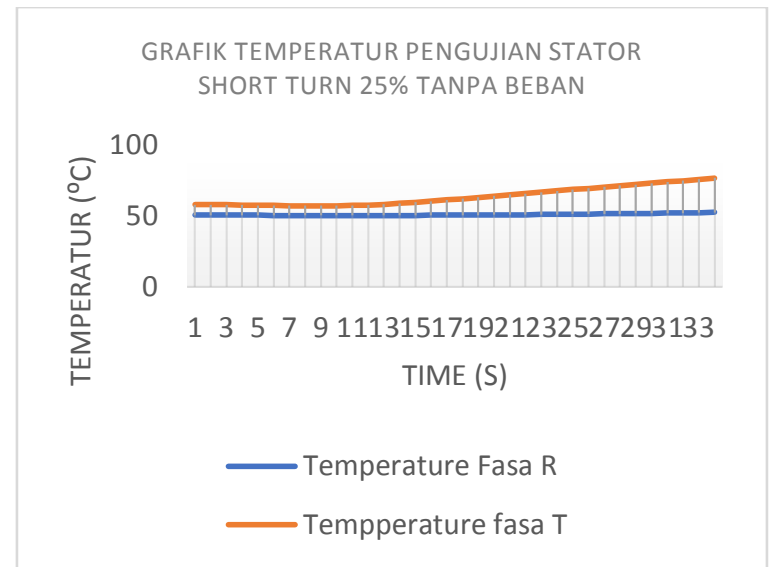

Gambar 9 Temperatur Short turn 25\%

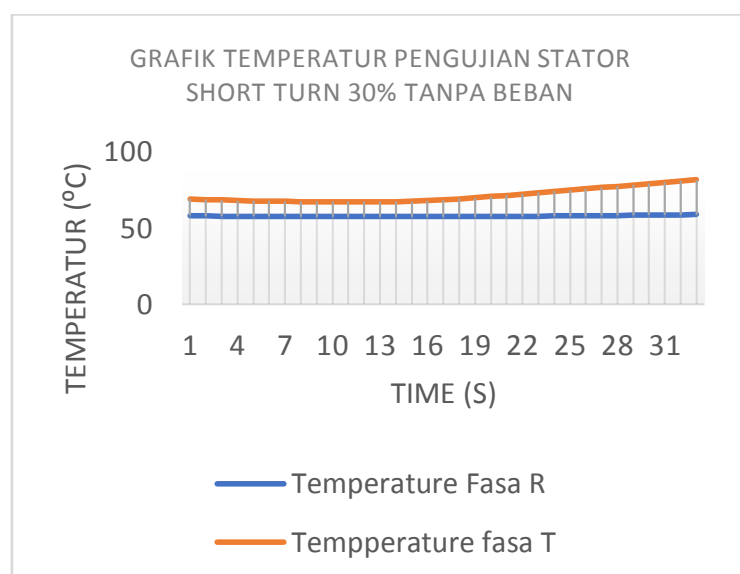

Gambar 10 Temperatur short turn 30\%

\section{Perhitungan Slip Dan Torsi Motor}

Perhitungan slip, eefisiensi dan torsi motor induksi fasa 3 ini berdasarkan data yang didapat dari pengujian gangguan stator motor induksi fasa tiga tanpa beban. Kemudian data yang didapatkan dari pengujian tersebut dimasukan kedalam perhitungan berdasarkan teori motor induksi fasa 3 yang telah dibahas Berikut ini tabel hasil perhitungan slip, effisiensi dan torsi motor induksi fasa 3 pada pengujian gangguan stator motor induksi tanpa beban. 
Tabel 3. Perhitungan motor tanpa beban

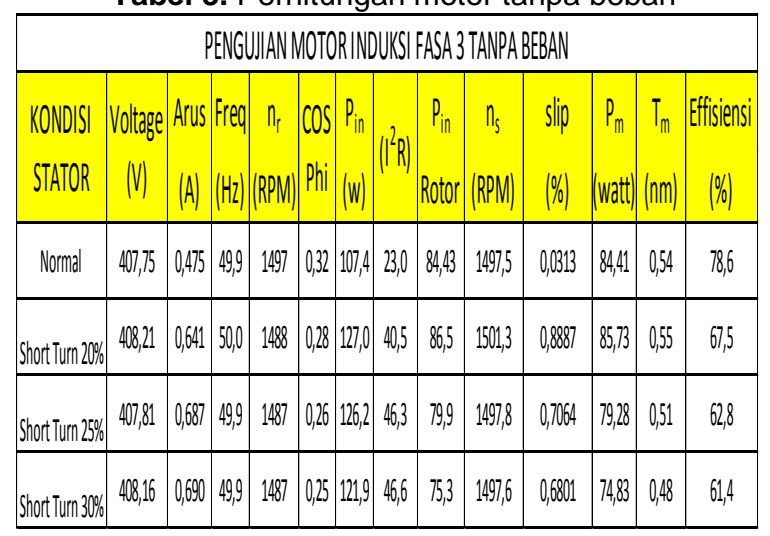

Tabel 4. Tabel perhitungan dengan beban

\begin{tabular}{|c|c|c|c|c|c|c|c|c|c|c|c|c|c|}
\hline \multicolumn{14}{|c|}{ PENGUJIAN MOTOR INDUKSI FASA 3 DENAGN BEBAN $25 \%$} \\
\hline $\begin{array}{l}\text { KONDISI } \\
\text { STATOR }\end{array}$ & $\begin{array}{c}\text { Voltage } \\
\text { (V) }\end{array}$ & $\begin{array}{c}\text { Arus } \\
\text { (A) }\end{array}$ & $\begin{array}{l}\text { Freq } \\
(\mathrm{Hz})\end{array}$ & $\begin{array}{c}n_{r} \\
\text { (RPM) }\end{array}$ & $\begin{array}{l}\text { COS } \\
\text { Phi }\end{array}$ & $\begin{array}{l}P_{\text {in }} \\
(w)\end{array}$ & $\left(I^{2} R\right)$ & $\begin{array}{c}P_{\text {in }} \\
\text { Rotor }\end{array}$ & $\begin{array}{c}n_{s} \\
\text { (RPM) }\end{array}$ & $\begin{array}{l}\text { slip } \\
\text { (\%) }\end{array}$ & $\begin{array}{c}P_{m} \\
\text { (watt) }\end{array}$ & $\begin{array}{c}\mathrm{T}_{\mathrm{m}} \\
(\mathrm{nm})\end{array}$ & $\begin{array}{l}\text { Eff } \\
\text { (\%) }\end{array}$ \\
\hline Normal & 409,91 & 0,476 & 50,0 & 1334 & 0,59 & 199,4 & 23,0 & 176,35 & 1500,5 & 11,10 & $\mid 156,66$ & 1,12 & 78,6 \\
\hline Short Turn 20\% & 409,99 & 0,659 & 50,1 & 1329 & 0,49 & 229,4 & 42,8 & 186,64 & 1503,9 & 11,60 & 164,87 & 1,18 & 71,9 \\
\hline Short Turn 25\% & 408,99 & 0,702 & 50,1 & 1315 & 0,48 & 238,7 & 48,4 & 190,34 & 1502,5 & 12,45 & 166,51 & 1,21 & 69,8 \\
\hline Short Turn 30\% & 408,95 & 0,718 & 50,0 & 1316 & 0,47 & 239,1 & 50,5 & 188,59 & 1501,2 & 12,35 & 165,18 & 1,20 & 69,1 \\
\hline \multicolumn{14}{|c|}{ PENGUJIAN MOTOR INDUKSI FASA 3 DENAGN BEBAN 50\% } \\
\hline $\begin{array}{l}\text { KONDISI } \\
\text { STATOR }\end{array}$ & $\begin{array}{l}\text { Voltage } \\
\text { (V) }\end{array}$ & Arus & $\begin{array}{l}\text { Freq } \\
(\mathrm{Hz})\end{array}$ & $\begin{array}{c}n_{r} \\
\text { (RPM) }\end{array}$ & $\begin{array}{l}\text { COS } \\
\text { Phi }\end{array}$ & $\begin{array}{l}P_{\text {in }} \\
\text { (w) }\end{array}$ & $\left(I^{2} R\right)$ & $\begin{array}{c}P_{\text {in }} \\
\text { Rotor }\end{array}$ & $\begin{array}{c}n_{\mathrm{s}} \\
\text { (RPM) }\end{array}$ & $\begin{array}{l}\text { slip } \\
(\%)\end{array}$ & $\begin{array}{c}P_{m} \\
\text { (watt) }\end{array}$ & $\begin{array}{c}T_{m} \\
(n m)\end{array}$ & $\begin{array}{l}\text { Eff } \\
(\%)\end{array}$ \\
\hline Normal & 410,23 & 0,609 & 50,1 & 1258 & 0,68 & 294,5 & 37,8 & 256,69 & 1501,7 & 16,21 & 214,91 & 1,63 & 73,0 \\
\hline Short Turn 20\% & 410,41 & 0,830 & 50,1 & 1200 & 0,63 & 371,8 & 67,8 & 304,01 & 1502,8 & 20,16 & 242,51 & 1,93 & 65,2 \\
\hline Short Turn 25\% & 408,57 & 0,928 & 50,0 & 1179 & 0,62 & 407,3 & 84,6 & 322,74 & 1501,3 & 21,47 & 253,23 & 2,05 & 62,2 \\
\hline Short Turn 30\% & 408,85 & 0,947 & 50,0 & 1176 & 0,62 & 415,7 & 87,7 & 327,97 & 1501,0 & 21,63 & 256,82 & 2,08 & 61,8 \\
\hline
\end{tabular}

\section{KESIMPULAN}

Dari hasil pengujian gangguan motor induksi fasa yang dilakukan dapat disimpulkan sebagai berikut:

1. Program Data Aqusition System (DAS) menggunakan perangkat lunak LabView dan perangkat keras NI USB 6009 dapat memonitoring kerusakan motor induksi fasa 3 terutama pada kerusakan stator short turn dengan menggunakan Metode Current Signature Analysis (MCSA).

2. Pada saat terjadi gangguan short turn stator motor induksi terjadi perubahan nilai arus motor induksi fasa tiga, nilai arus semakin meningkat seiring dengan meningkatnya nilainya persentase gangguan short turn stator, begitu pula pada nilai temperatur lilitan yang terhubung singkat, nilai temperature semakin meningkat pada saat terjadi gangguan short turn stator, nilai yang dihasilkan lebih besar dibandingkan dengan nilai temperatur pada lilitan normal.

3. Bentuk spektrum gelombang FFT arus menghasilkan bentuk gelombang yang yang memiliki noise dibeberapa frequency pada saat terjadi gangguan stator, bentuk gelombang yang dihasilkan memiliki nilai magnitude $(\mathrm{dB})$ yang semakin meningkat dan jumlah noise pada frequency yang semakin meningkat apabila dibandingkan dengan bentuk gelombang FFT arus ketika stator dalam keadaan normal.

4. Dampak yang di timbulkan dari gangguan short turn stator terhadap nilai slip yang dihasilkan semakin rendah dalam kondisi motor berbeban, dan nilai effisiensi motor yang semakin rendah ketika motor mengalami gangguan short turn stator, dan dampak yang ditimbulkan gangguan short turn stator terhadap nilai torsi yang semakin besar pada saat motor dalam kondisi berbeban.

\section{UCAPAN TERIMAKASIH}

Dalam penyusunan penelitian ini, saya ucapkan terima kasih kepada:

1. Bapak Hendro Tjahjono

2. Bapak Syaiful B., S.T., M.Eng.Sc., Ph.D.

3. Bapak Seflahir D., S.T., M.Pd.T.

4. Teman - teman yang telah membantu dalam proses penelitian yang tidak bisa disebutkan satu persatu.

\section{DAFTAR PUSTAKA}

[1] Kuswoyo, D. 2016. "Sistem Proteksi Motor Induksi 3 Fasa Dari Gangguan Tidak Seimbang dan Temperatur Lebih Menggunakan Mikrokontroller".

[2] Imamuudin, T. 2016. "Implementasi Metode Soft Starting Pada Motor Induksi 3 Fasa".

[3] Anthony. Z, 2014. "Motor Induksi" 
[4] Ghazali, R. 2011. "Metode perhitungan effisiensi motor induksi".

[5] Tugino, 2009 "Rekayasa Sistem Monitoringdan Analisis Temperatur Motor Listrik Berbasis Komputer". JFN, Vol 3 No. 2, November 2009 ISSN 1978-8738

[6] Jusni Sufrianti, Amir Hamzah, "Simulasi Dan Deteksi Gangguan Belitan Stator Motor Induksi Tiga Fasa Menggunakan Arus Starting Dengan Matlab/Simulink", Jom FTEKNIK Volume 4 No.1 Februari 2017

[7] Kiran G Mathure, Uttam B Vaidya, "Simulation Of Stator Winding Fault Of Three Phase Induction Motor Using Motor Current Signature Analysis",IJETST- Vol.03 Issue 08 Pages 09-13 August 2016 ISSN 23489480.

[8] Munthe, C. 2011. Rancang Bangun Alat Ukur Densitas dan Dosis Radiasi Sinar-X Pada Film Badge Dengan Menggunakan Sensor Cahaya $\mathrm{Cl}$ 6504A Berbasiskan Labview.

[9] Texas Instruments, 2016. LM35 Precision Centrigade Temperatur Sensors.

[10] Ade Kurniawan Putra, Dimas Anton Asfani, Dedet Candra Riawan, "Desain Peralatan Pendeteksi Gangguan Hubung Singkat Belitan Stator Motor Induksi Menggunakan Arus Online Berbasis Mikrokontroler", JURNAL TEKNIK ITS Vol. 4, No. 2, (2015) ISSN: 2337-3539. 